\title{
Relational pedagogy in a vocational programme in upper secondary school: A way to make more students graduate
}

\author{
Ulrika Gidlund
}

\author{
Mid Sweden University, Sweden (ulrika.gidlund@miun.se)
}

\begin{abstract}
In Sweden, many students start but do not graduate from upper secondary school despite preventive efforts. The reasons for students dropping out of school have been examined and opposed, but there is still more to be done. The overall aim of this study was to contextualise and understand teachers' and students' experiences and perceptions of relational pedagogy in a vocational upper secondary programme in Sweden. The theoretical framework was relational pedagogy to investigate theoretical knowledge of pedagogical relations. The data for this qualitative study was collected through two focus group interviews with 10 teachers and 10 individual student interviews. Directed content analysis was used to analyse the data in order to pay attention to the core concepts of relational pedagogy as a theoretical encoding scheme. The findings show that teachers and students find their working and learning atmosphere much safer and more secure compared to earlier; both groups mentioned relational pedagogy as promoting student participation, engagement, and motivation in school. This study contributes with knowledge of how vocational teachers and students perceive working with relational pedagogy to promote learning and school attendance, but there is still a need to find out more about how teachers' relational competence is acquired.
\end{abstract}

Keywords: dropouts, graduation, relational pedagogy, upper secondary school, vocational education

NJVET, Vol. 10, No. 2, 106-128 Peer-reviewed article doi: 10.3384/njvet.2242-458X.20102106 
Relational pedagogy in a vocational programme in upper secondary school

\section{Introduction}

Dropping out of upper secondary school is a major problem in the Western world. OECD (2019) claimed that $20-40 \%$ of students who enter upper secondary school have not graduated by the age of 25 . In Sweden, as in other countries, this may result in low educational levels, unemployment, low income, social problems (Lundahl, Lindblad, Lovén, Mårald \& Svedberg, 2017), criminality, and poor health (Holen, Waaktaar \& Sagatun, 2016) for students who do not graduate, and the issue has therefore been taken most seriously.

At the beginning of the 21st century, the level of youth unemployment in Sweden increased compared to other countries. A reform of upper secondary school was introduced in the autumn of 2011. One of the aims of this reform was the following: 'Everyone should reach the goals. The throughput should be high and students should complete their upper secondary diploma within three years. As few students as possible should drop out of their upper secondary education' (Skolverket, 2012, p. 12, my translation).

This has not worked out well. In Sweden, almost 97\% of students enter upper secondary school, but one out of three students does not graduate. These students either drop out at some time during the 3 years or do not reach the learning requirements for a diploma (OECD, 2019).

In one upper secondary school in Sweden, a project based on relational pedagogy has been in progress for 3 years, with the purpose of creating a vocational programme in which all students complete their education and receive grades from all subjects according to the diploma goals of the programme. The new pedagogical model focuses on the teachers being more educated in relational pedagogy, more social activities outside the classroom, individually adapted education, and more teachers in the classroom at the same time. The project aims to offer vocational education that is available to all, regardless of learning disability or difficulty, in which the students participate in their learning and have possibilities to succeed and become employable. The overall aim of this study was to contextualise and understand teachers' and students' experiences and perceptions of relational pedagogy in a vocational upper secondary programme in Sweden to find out how working with relational pedagogy can improve learning and school attendance in vocational education.

\section{Background}

This section will begin with a presentation of the context of parts of the Swedish school system, especially upper secondary school and its vocational education. Then, the background and problem with upper secondary school dropouts will 
be discussed from a Swedish and Scandinavian perspective. Finally, previous research on relational pedagogy will be presented and related to the theoretical framework of this study.

\section{The context}

The background and key concepts behind this study are of great importance for understanding the context in which this study arose. The discussion of related concepts is meant to explain the specific context of vocational upper secondary school in Sweden and the specific phenomena regarding upper secondary school dropout.

\section{Upper secondary school}

In Sweden, upper secondary school not only prepares students for higher education but can also prepare them for employment immediately after graduation. It is intended to provide them with a good foundation for active participation in society and personal development.

Upper secondary school in Sweden serves students aged 16-19. It runs for 3 years and is voluntary. There are 18 national programmes to choose from -12 vocational and six theoretical. There are also five introductory programmes for students who are not yet qualified for a national programme. After 3 years in a vocational programme, the student should be prepared to start working within the trade or profession he or she studied. Students are also taught basic competences to apply to higher education during these 3 years. In 2011, upper secondary schools emphasised that education must provide good specific preparation for higher education studies or for students' future working life (Skolverket, 2011).

\section{Many dropouts}

In upper secondary school, the proportion of youth who have failed some courses and therefore do not graduate or has dropped out is too high. One out of three students do not graduate from upper secondary school, either dropping out during the 3 years or not achieving the learning goals and grades (Skolverket, 2019; Thurfjell, 2017). The percentages are shown in Table 1.

Table 1. Students graduating from upper secondary school 2018.

\begin{tabular}{|l|c|}
\hline Programme & Graduated \\
\hline Theoretical programmes & $75.1 \%$ \\
\hline Vocational programmes & $70.2 \%$ \\
\hline Introductory programmes & $7.6 \%$ \\
\hline Total & $65 \%$ \\
\hline
\end{tabular}


There have been some studies on predictors of student dropout rates. Researchers from Scandinavia have detected that a low grade point average is a strong predictor of dropout in upper secondary school. Grade point average is, according to Sæle, Sørlie, Nergård-Nilssen, Ottosen, Bjørnskov Goll and Friborg (2016), related to many factors: cognitive and school-related aspects, such as learning difficulties and behaviour problems, and psychosocial factors such as mental illness, anxiety, and depression. Lundahl et al. (2017) also mentioned that student dropout might depend on students' lack of motivation related to a complex process resulting from a mixture of individual and contextual factors such as special educational needs (SEN), immigration status, or negative teacher-student relationships (TSRs). Holen et al. (2016) indicated that students with more positive TSRs are less likely to drop out than students with more negative TSRs. Krane, Ness, Holter-Sorensen, Karlsson and Binder (2017) explained that positive TSRs result in students being happier and having more positive attitudes towards school. Students who have dropped out have described negative TRS experiences.

In a Swedish report from a project funded by the European Social Fund (Temagruppen Unga i arbetslivet, 2013), 379 young people (188 girls and 191 boys) between 16 and 29 years old who had dropped out of upper secondary school (both vocational and theoretical programmes) were interviewed about their experiences. They were asked about their reasons for dropping out of school, what could have prevented the dropout, and their vision of a perfect upper secondary school.

For more than half of the interviewed students, bullying was the main reason for dropping out. They criticised the school staff for not acting even though they knew what was going on. The second most common reason was lack of pedagogical support when they did not reach the learning requirements, which led to anxiety, stress, low self-esteem, absenteeism, and finally dropping out. The dropout students also found the school environment too messy, loud, and chaotic and the classes too large. They described the teachers as tired, disrespectful, and not engaged. Some even described them as prejudiced, but others described teachers who cared about them and therefore had great importance in their lives.

Those who had dropped out of school thought it would have been different if they had had teachers who motivated them. They wanted engaged teachers who cared about and believed in them, teachers with reasonable demands who understand that students are unique and learn differently (Temagruppen Unga i arbetslivet, 2013).

To sum up, the predictors for dropping out are slightly different but most students and previous reviews refer to the quality of TSRs. With this in mind, the background and purpose of a project based on relational pedagogy in a vocational programme will be presented. 
A teacher team of a vocational programme at an upper secondary school in Sweden had experienced years when a lot of students dropped out or failed in many subjects and therefore did not graduate. In 2014, this teacher team initiated a new pedagogical model. Their aim was to create an educational model based on relational pedagogy to provide adequate conditions for all students, regardless of ability or disability, to fulfil their educational goals.

The purpose of changing the educational model was to give each student an individually adapted pedagogy, more responsibility, and the chance to form better relationships with their teachers, which in turn would lead to the students graduating and being employable (Specialpedagogiska skolmyndigheten, 2015). In the present study, these teachers' and students' experiences and perceptions of relational pedagogy in a vocational upper secondary programme in Sweden will be contextualised and examined.

\section{Previous research}

This section presents previous research on relational pedagogy and its related methods, approaches, or theoretical starting points to frame the research area.

\section{Relational pedagogy}

Good relationships between teachers and students have been an issue in pedagogical research since the beginning of this millennium (Cornelius-White, 2007; Hattie, 2012; Martin \& Dowson, 2009; Murray \& Pianta, 2007; Nordenbo, Søgaard Larsen, Tiftikçi, Wendt \& Østergaard, 2008; Roorda, Koomen, Spilt \& Oort, 2011). Because one of the greatest challenges for teachers today is initiating, maintaining, and developing good relationships with their students, which involves a relational perspective on pedagogy, Jensen, Bengaard Skibsted and Vedsgaard Christensen (2015) stated that it is important to note when talking about relational pedagogy that it is not about the teachers' quality but the quality of teaching. In Krane et al.'s (2017) study, the students found that what and how the teachers taught, as well as their demeanours, influenced them.

Teaching is an interaction between the teacher and the student. Darby (2005) indicated that teachers and students interact, and when doing so, the teacher always influences the students in a specific way, whether the teacher intends to or not. When interacting, the teacher and students reveal something about themselves, whether they intend to or not. A positive relationship with a teacher, according to Ryan and Deci (2000), causes a student to internalise some of the teacher's values and beliefs, which can be carried over into other school situations. Through good TSRs, students learn how to act and think in certain educational situations, which they then can apply to other more general circumstances.

Previous research has shown that relational pedagogy has some important advantages when it comes to learning. Findings from Cornelius-White's (2007) 
meta-analysis prove that positive TSRs lead to positive student outcomes; the opposite is also true. Positive TSRs lead to better teaching, as well as better teaching leads to better student outcomes. In the meta-analysis, Cornelius-White (2007) found that teacher variables such as positive TSRs, empathy, warmth, and encouragement of students' learning are more effective than other educational innovations. Also, Martin and Dowson (2009) found that positive TSRs improved students' motivation, engagement, and achievement in school. They detected that relationships are important for students' engagement and motivation at school. They concluded that high-quality interpersonal TRSs in the students' lives correlated with students' motivation, engagement, and achievement. Krane et al. (2017) also found that positive TSRs promote students' well-being and motivate them to attend school. To learn more about TSRs' connection to students' learning achievement, Ljungblad (2019) developed a theoretical perspective on relational teachership based on previous research on didactics and relational pedagogy. To develop a better understanding of TSRs and their importance for students' achievement, she added the didactic triangle to highlight various aspects of TSRs.

The result of TSRs differs depending on the nature of the student. In Roorda et al.'s (2011) study of the relationship between TSRs and students' school engagement and achievement, their analysis showed positive connections between good TSRs, engagement, and achievement, as well as negative connections between negative TSRs and negative engagement and achievement. Unexpectedly, and in contrast to previous assumptions, positive TSRs were more important to upper secondary students' engagement and achievement than to that of younger students. For primary school students, negative TSRs were more strongly related to negative engagement and achievement than for upper secondary students. This study showed that positive TSRs are more important for older students, and negative TSRs are more devastating for younger students when it comes to engagement and achievement. In further analysis, the researchers also found that students with SEN and learning difficulties and other at-risk students were more strongly sensitive to the quality of TSRs than other students (Roorda et al., 2011). This is in line with Murray and Pianta's (2007) study, in which the researchers also noticed the importance of good TSRs for students' mental health and socialemotional functioning. Ljungblad (2019) also claimed that it is important to examine how good TSRs can provide better opportunities for at-risk students and students with SEN who are in need of alternative and more effective interventions.

Different studies characterise relational competence slightly differently, or using different subcategories. Jensen et al. (2015) studied TSRs both theoretically and practically. The purpose of their project was to fill in both theoretical and empirical knowledge gaps, to further understand the importance of TSRs, and to map the theoretical landscape more thoroughly. The researchers distinguished 
six central sub-elements of the concept of relational competence: context, appreciation, change of perspective, empathy, attention, and presence of mind (Jensen et al., 2015). Comparable to Jensen et al. (2015), Darby (2005) identified in her study six categories within three spheres of relational influence that students perceived through positive TSRs: passion (enthusiasm), comfort (friendly, nonthreatening, comfortable environment; being 'friends' with the student; sense of humour), and support ('help', being attentive to their needs, responsive, and fair and acknowledging all students in an encouraging way).

The age of students is not the only vital factor when it comes to the importance of positive TSRs (Roorda et al., 2011); the type of teacher also matters. Aspelin (2018) suggested that expectations and demands of relational competence differ depending on the type of teacher. When vocational and subject teachers in upper secondary schools are compared, some differences in relational competence become evident. A vocational teacher spends much more time in the classroom with students than a subject teacher does (Köpsén, 2014; Mårtensson, Andersson \& Nyström, 2019). Consequently, the relationship between the student and the vocational teacher is more important. Furthermore, Köpsén (2014) explained that a vocational teacher is an expert in the trade the student intends to master and a role model for the professional craftsmanship the student wants to achieve. Previous research claimed that being a role model and a teacher for a specific professional vocation requires a certain amount of striving towards the vocation but also balancing the amount of closeness to and distance from the students (Aultman, Williams-Johnson \& Schultz, 2009; Fejes \& Köpsén, 2014; Köpsén, 2014; Lippke, 2012; Nylund \& Gudmundson, 2017).

When investigating relational pedagogy in Sweden, it is impossible not to refer to Aspelin's thorough research. Aspelin $(2006,2018)$ used Scheff's $(1990)$ social psychological perspective to develop a theory of teachers' relational competence. According to Scheff's (1990) theory, the social bond is a central concept. Humans need to build social bonds with other humans, and that is true for teachers and students as well. These social bonds by nature can be built, repaired, threatened, or even cut off (Aspelin, 1996).

The teaching profession, which is closely dependent on relationships, could be viewed (according to Scheff, 1990) as an ongoing process of communication in which the teacher's communication develops the relationship with the student. Aspelin $(2006,2018)$ talked about three competences on which relational pedagogy is based. The first, communication competence, deals with what people say to each other (verbal communication) and how they act in relation to each other (nonverbal communication). It is about how well they cognitively understand each other and whether they show each other adequate respect in an emotional aspect. The second, differentiation competence, deals with the degree of closeness and distance in the TSR. The teacher must be aware of the fine boundaries between being too close or too much of a friend and being too distant, too much 
of a remote instructor. Being too much of either could be devastating to a good TSR. The third and last is the teachers' socio-emotional competence, which relates to the emotional indicators the teacher has to cope with. Socio-emotional competence refers to a teacher's ability to deal with and encourage a student to feel pride and prevent him or her from feeling shame. Shame and pride are important feelings in because they impact how a student believes he or she is valued by others (Aspelin, 2006, 2016, 2019; Aspelin \& Jonsson, 2019). Relational pedagogy is a theoretical perspective that focuses on teaching as a communicative human interaction and as a relational process (Aspelin, 2018; Ljungblad, 2019).

To sum up, the interactive relation between people has an impact on both the context and the people involved in it. If teachers of vocational programmes create sound relationships with students, this will lead to better learning for the students. Therefore, relational pedagogy as a theoretical framework is used to understand the importance of relationships in vocational education in this article.

\section{Theoretical framework}

The present article is a study of vocational teachers' and students' experiences and perceptions of working with relational pedagogy. The theoretical framework of this study is based on Aspelin's definition and research on relational pedagogy, in which it could be studied through three competences: (a) communication, (b) differentiation, and (c) socio-emotional. These three competences must be seen as analytical categories. Aspelin and Jonsson (2019) clarified that one cannot separate one competence from another in real life. Communicative competence, differentiation competence, and socio-emotional competence are only theoretical tools that can help us to identify aspects of teachers' communication, interactions, and actions to develop theoretical knowledge of pedagogical relations.

\section{Overall aim}

In Sweden, the proportion of youth who dropout of upper secondary school or fail some courses and therefore not graduate is too high. It is therefore most important to generate and improve new knowledge of the reasons for, and prevention of school dropout. The overall aim of this study was to contextualise and understand teachers' and students' experiences and perceptions of relational pedagogy with regard to learning, and school attendance in a vocational upper secondary programme in Sweden.

\section{Research questions}

- How do upper secondary vocational teachers and students describe their experiences of working with relational pedagogy? 
- What advantages and difficulties do the upper secondary vocational teachers and students articulate regarding working with relational pedagogy to promote learning and school attendance?

\section{Methodology (materials and methods)}

A qualitative research design of directed content analysis was used to address the research questions (Hsieh \& Shannon, 2005; Krippendorff, 2018).

\section{Methods of data collection}

The primary sources of this study were data collected through focus group interviews and individual follow-up interviews with the teachers who had worked with relational pedagogy.

The empirical data on the teachers' understanding and attitudes were collected through two focus group interviews with four to six teachers of the same teacher team. In one group, all six teachers had been initiators of the project, and in the other group, the four teachers had started working at the school after the project had already started. Focus group interviews with the teachers were used as a method of data collection to let the interviews function as their normal teacher team meetings rather than having them answer questions about their experiences and perceptions. The teachers were divided into two different groups so that the difference in their entrance into the project would not influence their discussions. The 10 interviewed teachers were all the teachers involved in the project at the end of the project. The empirical data also consisted of 10 individual follow-up interviews all conducted in June 2018.

The focus group interviews were based on stimulus texts containing quotations from the application of this project to encourage the interviewees to express their personal values and ideals in relation to specific social and cultural contexts (Törrönen, 2002), in this case, Swedish vocational upper secondary schools. The interviews were recorded with a video camera and a voice recorder to make it easier to keep track of who said what when analysing the material. The total empirical materials consist of about two hours of audio- and videotaped discussion, about one hour per focus group interview, and were transcribed into 19,310 words.

The students who had been working according to relational pedagogy were also interviewed about their perceptions of the project. The data on students' perceptions were collected through individual interviews based on a semi-structured interview guide. They were transcribed into 23,104 words. All students who had been involved in the project from the first year were asked to take part in the interviews, but for different reasons, only 9 out of 17 attended. 


\section{Qualitative content analysis}

Qualitative content analysis with a directed approach (Hsieh \& Shannon, 2005) was used to analyse the data. Because the data were collected through focus group interviews and individual interviews with a focus on relational pedagogy, it was possible to pay attention to the core concepts of relational pedagogy as a theoretical encoding scheme. Hsieh and Shannon (2005) explained that prior research or theoretical models can be used to identify key concepts or variables as initial coding categories. Elo and Kyngäs (2008) called it deductive content analysis, in which a structured matrix of analysis based on a model can be used. The themes that ran across both the teachers' and students' interviews were therefore identified deductively according to the three analytical categories of relational pedagogy.

The analyses began with a construction of a coding scheme based on relational pedagogy and a division of the different interviews. The meaning units were divided into three domains: (a) teachers initiating the project, (b) teachers coming into the project after it had started, and (c) students involved in the project. The analyses of the interviews from the three domains were made separately but with the same coding scheme and performed, as described in Figure 1.

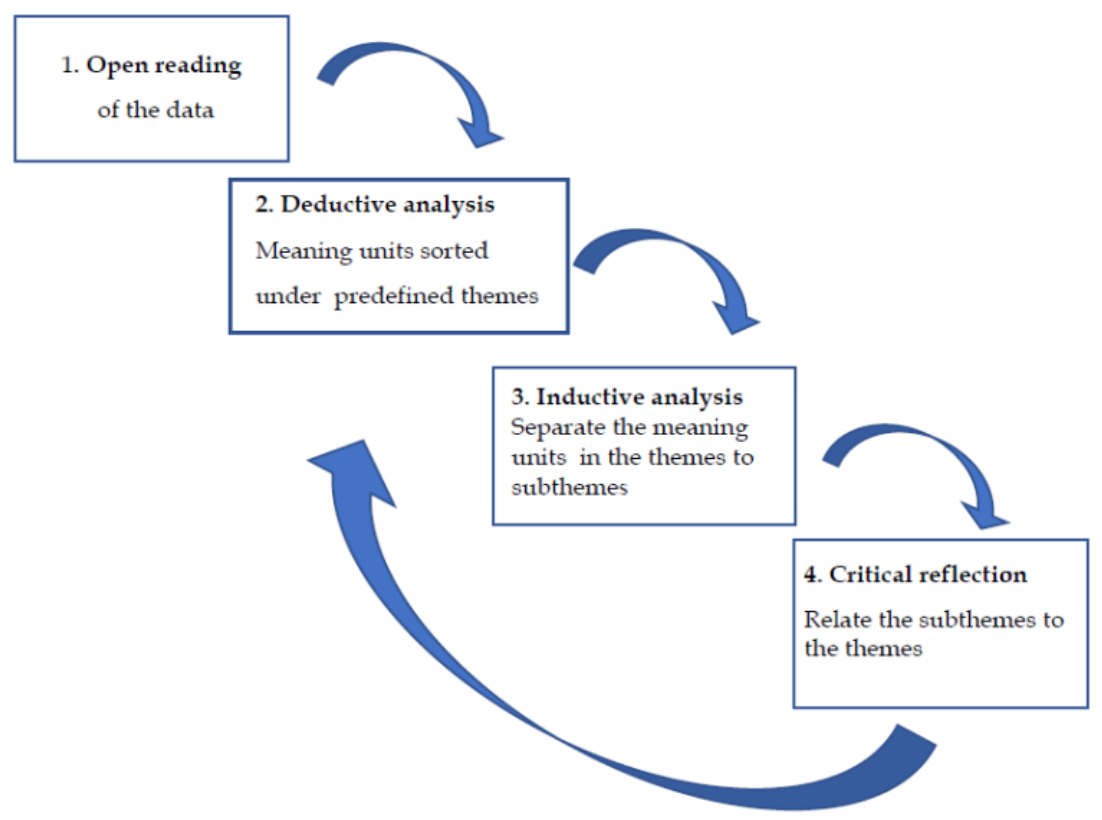

Figure 1. The steps in the analysis, inspired by Rising Holmström, Häggström, and Kristiansen (2015). 
First, statements about relational pedagogy were identified through an open reading to obtain an overall impression of the interviews' content. In the second step, meaning units representing the predetermined themes of the existing theory of relational pedagogy were highlighted. Third, the various meaning units were coded using the predetermined themes. Fourth, the meaning units sorted in the themes were then separated into subcategories depending on their characteristics (see Table 2). The analysis involved a constant moving back and forth throughout the entire data set, the coded extracts of data analysed, and the analysis of the data produced. Data that were not coded were analysed to decide whether they could create a new theme or subtheme and labelled them 'Other.' Parts of the analysis process were discussed with experts to ensure the reliability of the themes and subthemes.

Table 2. Example of the analysis process.

\begin{tabular}{|l|l|l|}
\hline Meaning unit & Subtheme & Theme \\
\hline $\begin{array}{l}\text { 'We call each other colleagues, not teacher and } \\
\text { student' }\end{array}$ & What they say & Communication \\
\hline $\begin{array}{l}\text { 'We keep the students not too close, and not too } \\
\text { distant' }\end{array}$ & Balance & Differentiation \\
\hline 'No one judges you here. You can be yourself!' & Safety & Socio-emotional \\
\hline 'No consensus in the teacher team' & Disadvantages & Other \\
\hline
\end{tabular}

The Swedish Research Council's rules for good ethical research in the humanities and social sciences were followed in this study regarding individual protection of information, consent, confidentiality, and use (Hermerén, 2011). All teachers participated voluntarily in the study after a written presentation in which they were assured anonymity. Each individual was guaranteed anonymity through encoding. Therefore, no findings are linked to any individual teacher or student.

\section{Results}

In the following section, empirical data will be presented and analysed.

Because the empirical data derive from three sources, the meaning units of the empirical data were divided into three domains and analysed separately. The domains are as follows:

(a) The understanding of the teachers initiating the project

(b) The understanding of the teachers coming into the project after it started

(c) The understanding of the students involved in the project 
The results of the analysis are therefore presented under separate subheadings and analysed according to three themes; then, in the next section, they are discussed together in relation to previous research.

\section{The understanding of the teachers initiating the project}

Within this first domain, how the upper secondary vocational teachers initiating the project described their experiences of working with relational pedagogy will be examined.

The teachers mentioned the difference in both what and how they communicated with the students. One advantage they mentioned was that when teachers worked together, the students received various explanations of difficult tasks from several teachers and thus in many different ways. The classroom doors were open, and often two teachers were scheduled in the same class at the same time. This resulted in them helping each other to present explanations to the students. One teacher explained, 'For the students, if they don't understand one explanation they go to another [teacher] and get another explanation, and then they understand.'

This strengthened the students as well as the teachers. The teachers improved their communication competence. One teacher said, 'We try to see every student as an individual and make it understandable and comprehensive for each student. I don't think we really did that before. We just taught.'

They also described how important the differentiation competence was. They stated how important it is with relationships and being friends but also to be honest with all students that they have to work hard in their studies. One teacher said that not doing that 'is like deceiving the students, in a way.' Another teacher stated that when the teacher is too much of a friend, 'there are no one telling them what consequences their behaviour will lead to.' They claimed that it is important that teachers require students to keep up with their studies. They also found out during the project that dropping out of the programme did not have to be negative for the student. With better TSRs and effective communication, teachers found it easier to guide the students who were in the wrong vocational programme, such as those who did not desire to become electricians or plumbers, and to help these students get a fresh start in a vocational or theoretical upper secondary school programme of their choice. One teacher explained, 'If they want to become good craftsmen, which is our goal, they have to jump on the train. If not there will be consequences.'

The teachers also stressed socio-emotional competence and what it brought to the students. They got to know the students better as individuals and as well as students; all students' learning abilities or disabilities were identified, and teaching was adapted to them. The teachers accordingly knew more about each student's preferences in the classroom. One teacher explained, 'It is easier to identify 
[the students' individual needs] and meet them.' They also found it easier to contact the students for whatever reason. Better relationships led to higher degrees of student responsibility and made it easier for students to contact teachers when they needed to. Another teacher said, 'It is easier for them to contact us too.' One more advantage of relational pedagogy the teachers claimed was that it enabled the students to know each other earlier and more deeply, which made a difference in their learning motivation. The first week they only worked on bringing the class together. One teacher said that in the new classes, 'to work during the first days. To make them feel welcomed, and to get to know each other.' Another teacher claimed that, for the socio-emotional atmosphere, 'The camp [during the first week] and the get-to-know exercises are important.'

With positive TSRs, the teachers also believed that the students felt safer, which in turn reduced their chances of becoming at-risk students. They claimed that the more comfortable the students felt at school, the more meaningful they found their studies. One teacher also referred to the parents as being more satisfied, as they would say such things as 'What has happened with my son or daughter now? She/he has never been like this before. She/he wants to go to school and is successful there, far more than ever before.' Another teacher explained that he had interviewed the students with the same question for a couple of years and states that, 'There is a much more positive atmosphere now than before. Something must have happened.'

The aim of the project was to make all students graduate. One teacher stated clearly that the goal was not achieved and would not be. Another one claimed, 'We haven't developed enough because of many different reasons, but I think our goal is clearly achievable. We are only in the beginning, but I think we could reach it. I'm totally convinced that we will!' One of the difficulties mentioned was the lack of consensus within the project's teacher team. Some teachers just did not want to work with relational pedagogy, which made the rest of the teachers in the teacher team frustrated and frail. When confrontations amongst the teacher team occurred, one teacher described the team as being covered with 'a negative black blanket.' The teachers explained their lack of consensus among and problems with recruitment and blamed them on a weak management and headmaster. The teachers felt that the project was successful in many ways but were aware that not everything they had hoped for had become real. Other positive changes occurred instead. One teacher said, 'It might not have turned out exactly the way we planned, but it has given us so much else.' The project has also spread, and other teachers at other schools have adopted the model. The same teacher said, 'We have discovered something that could work here, and there are others that work this way, almost even more than we do.'

In summary, the teachers initiating the project described their experiences with relational pedagogy as positive in terms of the effects it had on their working situation and on the students. Their descriptions were based on the effects of 
improved communication and socio-emotional competence. They were also more conscious of the fragility with differentiation. They were, anyhow, aware that the project could have been even more effective with stronger management.

\section{The understanding of the teachers coming into the project after it started}

In this domain, the analysis was intended to help to understand how upper secondary vocational teachers coming into the project after it started described their experiences of working with relational pedagogy.

These teachers also highlighted the differences in both what and how they communicated with the students. One of the teachers explained, 'We call and treat each other as colleagues instead of teacher/student.' Another one said, 'Instead of me being a teacher and them being students, we are co-workers who work toward the same goal.'

Improved communication enabled the teachers to interact with the students differently. In teaching situations, they also felt they had improved. One teacher explained, 'We have learnt how to handle the students and talk to them in a way that they understand.'

The teachers had opportunities to guide and tutor the students according to what the latter wanted for their future. They also helped students to find out what they wanted to do and become. One teacher explained, 'It is easier to guide them to the right programme now.' The teachers claimed that students actually had a lot of supervision when it came to their vocational plans.

They also described how important their differentiation competence was. One teacher explained, 'You balance on a very narrow line. You should not be too close, and not too distant from the students.' The teachers felt it was important to stress the boundary between being a friendly teacher and being a friend. Another teacher said, 'You gain more respect by having a good relationship, but there must be some distance so you can set boundaries for things.' Differentiation competence seems to be the competence these teachers found most difficult to accomplish.

The teachers mentioned socio-emotional competence as the most effective approach, stressing that there is nothing without good relationships. When relationships are solid between students and teachers, all earn and show more respect. Thanks to the relational pedagogy project, the teachers felt they really got to know the students better, which helped them to better know how to make the students understand. The teachers learnt how to best respond to and match the students in their learning and working processes. They also clarified that when the students found school fun, they would always show up, participate, and thus learn. One teacher said, 'I think like this, I have these students, I want them to feel safe and secure here, I want them to participate and have fun.' Another teacher explained, 'Now, school is a place the students want to go to. Everybody socialises with almost everybody.' 
Overall, the teachers concluded that although they cannot make all students graduate through relational pedagogy, they can help more reach that point. One teacher speculated, 'We might not reach the goal of 100\% to graduate, but instead of $80 \%$, we might reach $90 \%$ or $95 \%$.' Another one agreed and continued, ' $100 \%$ is doubtful. But it is a goal to constantly strive for.'

Although the working and learning atmosphere improved greatly, the teachers still felt difficulty within the teacher team. Similarly, to the teachers who initiated the project, these teachers did not feel that they belonged to a team - they were just individuals working with the same students. These teachers also believed that the project would have been much more effective if management had been more distinct and determined towards the teacher team.

\section{The understanding of the students involved in the project}

The analysis of the third domain determined how the upper secondary vocational students involved in this project described their experiences with relational pedagogy.

The students, of course, viewed relational pedagogy a bit differently. They mentioned differences in both what and how the teachers communicated with them and what changes the communication made. One student said, 'It depends more on how the teachers are as persons than the way they teach. If they are merry and open, it is easier to learn.' The students also claimed that they received more and quicker help with their assignments, confirming that they received individual help because the teachers all believed in adapted learning. They described their teachers as excellent, driven, and positive; one student said, 'I haven't had one single bad teacher, at least as far as I can remember.'

Students also discussed how important differentiation competence was, as they did not want the teachers to be too friendly at the expense of being too little teachers. One student explained that teachers must behave as teachers, saying, 'The teachers must see who is working and who is not and then tell those who aren't to start working.' Another one who wanted the teachers to be friendlier said, 'You can actually talk and work at the same time, and teachers know that.' Students had different opinions on how close or distant they wanted the teachers to be. They also experienced that, in relation to the project, they were given the responsibility to complete tasks by themselves, which gave them a sense of professional pride.

The students put the strongest focus on socio-emotional competence and what it brought to their studies. They explained that the teachers being good-humoured and open made it easier to learn; when students harmonised with teachers, they also harmonised with the course content and subject, which made them feel that their studies would be interesting throughout the rest of their education.

One advantage described took place at the start of the semester, when all the new students and their new teachers went on a joint overnight excursion with 
students from other grades. The students attested that getting to know each other at the beginning was a great start socially that made the rest of the school year a more positive experience. Students confirmed that working with relational pedagogy made it easier for them to relate better to peers and teachers. One student described the atmosphere as follows: 'Here you can be yourself, take the time you need, and really feel secure.' Another one said, 'I got the impression that both teachers and students actually are behaving well here. It makes you feel safe and secure.' A third said, 'No one judges you here at school. You can be yourself.'

The students also stated that they felt that education had become more interesting. The change in pedagogical model had led to a change in learning and teaching methods. The students spoke positively about their relationships with their peers, explaining that it was fun to be in school with their friends, which in turn made them work harder. One student said, 'It has given me very good friends that I will keep for the rest of my life. That is really awesome.' They described school as always fun to go to because they knew their peers would be there, and because of their presence, school days would be fun.

In summary, the teachers explained that better TSRs enabled them to know the students better, which (a) led to a more respectful atmosphere, (b) made it easier to individualise and adapt teaching to students' needs, (c) made it easier to guide and tutor the students, (d) promoted higher student responsibility, (e) promoted better student participation and motivation, (f) provided more time to collaborate with colleagues and learn from each other, and (g) strengthened their vocational identities.

The students explained that better TSRs led to (a) more individualisation by adapted learning, (b) finding school more fun and thus working harder, (c) feeling more secure and safe at school, (d) larger interest in the vocation, and (e) higher professional pride. Better relationships amongst students also led to school being perceived as more fun, thereby prompting more participation and feelings of security and safety at school.

In terms of how teachers and students described working with relational pedagogy, all three analytical categories were highlighted, but in different ways. The teachers described their improved communicative competence, in terms of both what they said and how they communicated with the students, as well as their differentiation competence, as something difficult but important to keeping a good balance between closeness to and distance from the students. They spoke mostly about how their augmented socio-emotional competence improved the working and learning atmosphere in various ways. The students described the teachers' communicative competence as how nice and easy to talk to they were and their differentiation competence as how the teachers balanced friendliness and teaching. The students also described socio-emotional improvement as the most effective competence; they felt safe and secure and that the teachers were doing their job. 
The teachers also articulated some difficulties of the project that could be strengthen by working more distinctly with relational pedagogy. The difficulties were (a) balancing the degree of closeness and distance, (b) lack of consensus in the teacher team, (c) weak management, and (d) recruitment problems. Clearer communication and differentiation would strengthen the consensus in the teacher team and the management, respectively, and through better socio-emotional competence, working conditions would improve, enticing more teachers to apply for a job at that school and thus solving the recruitment problems.

\section{Discussion}

The overall aim of this study was to contextualise and understand teachers' and students' experiences and perceptions of relational pedagogy in a vocational upper secondary programme in Sweden. With inspiration from Aspelin's theoretical approach to relational pedagogy (e.g., Aspelin, 2006; Aspelin \& Jonsson, 2019), the teachers' focus group discussions and students' interviews were analysed with a focus on the articulated advantages and difficulties of working with relational pedagogy to promote learning and school attendance.

The teachers focused on the advantages because they noticed higher student participation, motivation, and school attendance, which is in line with Martin and Dowson's (2009) review. They also claimed that improved TSRs made it easier to guide and tutor the students, which led to the students gaining better insight into the teachers' values and beliefs in not only school situations, as Ryan and Deci (2000) found, but also workplace ones. The teachers in this study said that working on the project strengthened their vocational identities, and that they could therefore be better role models for the craft that Köpsén (2014) claimed vocational teachers aim for. During the project, the vocational teachers developed a meta-knowledge of their elaborated relational competence and its consequences, which is notable in their discussions. They have become more aware of TSRs' importance for teaching and for fostering craftsmen.

The teachers and students in this study both emphasised that there must be a balance between how close or distant vocational teachers are to their students. This has been discussed extensively in other studies (Aultman, Williams-Johnson \& Schultz, 2009; Fejes \& Köpsén, 2014; Köpsén, 2014; Lippke, 2012) and must therefore be viewed as one of the most difficult issues when working with relational pedagogy. Aspelin (2018) stated that being too close or too distant could be devastating to positive TSRs. Vocational teachers spend much more time with the students experiencing this balance, and the consequences of being either too close or too distant are more evident with these teachers than with others. Even though this competence is important for students' learning and school attendance, it is not clear whether it is a competence a teacher could learn or develop. 
This project was implemented in an upper secondary school vocational programme. The teacher team were strengthened by additional teachers, and they had prepared to develop positive TSRs by studying research and practical manuals on relational pedagogy. The teachers' increased relational competence enabled them to improve the students' learning and school attendance. This ability is notable in the results of the students' opinions, which indicate a focus on the advantages of TSRs, and is in line with the results of Roorda et al. (2011), confirming that positive TSRs are very important to upper secondary students' engagement and achievement. The teachers in this project also mentioned that the programme comprised many students with a variety of special needs. Previous research has proven that positive TSRs are even more effective for the learning and participation of students at risk or with SEN (Murray \& Piantas, 2007; Roorda et al., 2011). In another school form or classes without students with SEN, the results might have been different. However, this study does confirm the claims of prior researchers.

\section{Conclusions}

The overall conclusion of this study is that the teachers and students of the three domains experienced improvements to their working and learning environments through working with relational pedagogy, but in slightly different ways. The teachers initiating the project wanted a change from what they had experienced earlier, the teachers coming into the project after it had started could not compare it with anything, and the students did not experience the management of the project. However, the results showed that all participants experienced effects of relational pedagogy on the working and learning environments.

The teachers and students both pointed out that their working and learning environment became more satisfying when working with relational pedagogy. Because of their consciousness of socio-emotional competence, the atmosphere improved between teachers and students, students and students, and teachers and teachers (with some exceptions). The consequences of these pedagogical changes affected the entire working and learning situation and promoted the students' learning and school attendance. The students explained that when going to school was fun, they would go, participate, and learn. When students were on good terms with teachers, they were on good terms with the subjects they were teaching. They also mentioned that better communicative competences provided better opportunities to adapt and individualise their lessons, and that positive TSRs were necessary for effective mentoring and tutoring of students.

Another conclusion is the concern of both teachers and students about the consequences of teachers becoming too close or too distant. The students expressed that an ideal teacher would be friendly and nice, but still an authority. The teach- 
ers were aware of this and discussed the difficulties with this balance. The differences in the individual contexts and expectations of individual students demand sensitivity and sure instinct in each individual situation.

Finally, this study concludes on the importance of strong management, especially considering that not all teachers in the teacher team were willing to change their pedagogy. The teachers in this study were disappointed with the management, believing the project would have been even more effective if they had consensus within the teacher team. They accused the management of being too weak and absent to support the project as needed.

The study of TSRs is important for understanding qualitative factors within the classroom. Even though various aspects of TSRs and student learning outcomes have been emphasised in many empirical studies, research reviews, and meta-analyses, according to Jensen et al. (2015), little is known of how teachers' relational competence is acquired; there are no fixed methods or approaches within relational pedagogy. The field is still too undefined and unexplored, but a theoretical starting point needs to be developed as an area for creating new knowledge (Aspelin, 2018; Aspelin \& Persson, 2011). Jensen et al. (2015) supported this concept by confirming that the research field is in its infancy and needs to be further developed to generate more knowledge of TSRs' importance for students' knowledge achievement.

This study has though contributed to the research field by presenting how students and teachers perceive various teacher relational competences as improving the students' learning and school attendance in vocational programmes. To develop and/or generate more knowledge of relational pedagogy this study has focused on upper secondary teachers' and vocational programme students' experiences. By focusing on the importance of teachers' verbal and nonverbal communication, the difficulties and importance of the teacher to balance being too close or too distant from the student, and the importance of students feeling safe and respected at school, the results show the teachers' and students' positive perceptions of relational pedagogy in terms of learning and school attendance, as well as the difficulties they find in implementing it.

However, there is still a need for further research, especially because previous research has already claimed that the research field of relational pedagogy needs to be further developed empirically and theoretically (e.g., Aspelin, 2018; Aspelin \& Persson, 2011; Jensen et al., 2015). Some potential areas for further research are (a) students' grades and results with regard to relational pedagogy, (b) the workload for teachers and/or management when working with relational pedagogy, (c) other ages or school forms (preschool to university) to strengthen the metaanalysis of Roorda et al. (2011), and (d) what actual activities, tools, or methods for good TSRs work and when. TSRs are important for students' outcomes, but even Jensen et al. (2015) claimed that too little is known of how teachers' relational competence is acquired. From this study, it is obvious that when teachers 
Relational pedagogy in a vocational programme in upper secondary school

improve their communicative, differentiation, and socio-emotional competences, working and learning atmospheres become more positive for all and promote the students' learning and school attendance.

\section{Note on contributor}

Ulrika Gidlund is a Senior Lecturer at the Department of Education at Mid Sweden University, Sweden. Her research interests focus on special educational needs, inclusive education and relational pedagogy in upper secondary school. She is also teaching on the department's different teacher education programmes and courses, especially at the teacher education for upper secondary school teachers. 


\section{References}

Aspelin, J. (1996). Thomas J. Scheffs socialpsykologi. Sociologisk forskning, 33(1), 71-86.

Aspelin, J. (2006). Beneath the surface of classroom interaction: Reflections on the microworld of education. Social Psychology of Education, 9, 227-244.

Aspelin, J. (2016). Om den pedagogiska relationens gränser: Relationskompetens i gränslandet mellan närhet och distans. Nordisk Tidskrift för Allmän Didaktik, 2(1), 3-13.

Aspelin, J. (2018). Lärares relationskompetens: Vad är det? Hur kan den utvecklas? Stockholm: Liber.

Aspelin, J. (2019). Enhancing pre-service teachers' socio-emotional competence. International Journal of Emotional Education, 11(1), 153-168.

Aspelin, J., \& Jonsson, A. (2019). Relational competence in teacher education. Concept analysis and report from a pilot study. Teacher Development, 23(2), 264-283.

Aspelin, J., \& Persson, S. (2011). Om relationell pedagogik. Malmö: Gleerup.

Aultman, L.P., Williams-Johnson, M.R., \& Schutz, P.A. (2009). Boundary dilemmas in teacher-student relationships: Struggling with "the line". Teaching and Teacher Education, 25, 636-646.

Cornelius-White, J. (2007). Learner-centered teacher-student relationships are effective: A meta-analysis. Review of Educational Research, 77(1), 113-143.

Darby, L. (2005). Science students' perceptions of engaging pedagogy. Research in Science Education, 35, 425-445.

Elo, S., \& Kyngäs, S.H. (2008). The qualitative content analysis process. Journal of Advanced Nursing, 62(1), 107-115.

Fejes, A., \& Köpsén, S. (2014). Vocational teachers' identity formation through boundary crossing. Journal of Education and Work, 27(3), 265-283.

Hattie, J. (2009). Visible learning: A synthesis of over 800 meta-analyses relating to achievement. London: Routledge.

Hermerén, G. (2011). God forskningssed. Stockholm: Vetenskapsrådet.

Holen, S., Waaktaar, T., \& Sagatun, $\AA$. (2018). A chance lost in the prevention of school dropout? Teacher-student relationships mediate the effect of mental health problems on noncompletion of upper-secondary school. Scandinavian Journal of Educational Research, 62(5), 737-753.

Hsieh, H.F., \& Shannon, S. (2005). Three approaches to qualitative content analysis. Qualitative Health Research, 15, 1277-1288.

Jensen, E., Bengaard Skibsted, E., \& Vedsgaard Christensen, M. (2015). Educating teachers focusing on the development of reflective and relational competences. Educational Research Policy Practice, 14(3), 201-212.

Krane, V., Ness, O., Holter-Sorensen, N., Karlsson, B., \& Binder, P.E. (2017). You notice that there is something positive about going to school: How teachers' 
kindness can promote positive teacher-student relationships in upper secondary school. International Journal of Adolescence and Youth, 22(4), 377-389.

Krippendorff, K. (2018). Content analysis: An introduction to its methodology. Thousand Oaks, CA: Sage.

Köpsén, S. (2014). How vocational teachers describe their vocational teacher identity. Journal of Vocational Education E Training, 66(2), 194-211.

Lippke, L. (2012). “Who am I supposed to let down?" The caring work and emotional practices of vocational educational training teachers working with potential drop-out students. Journal of Workplace Learning, 24(7/8), 461-472.

Ljungblad, A.L. (2019). Pedagogical relational teachership (PeRT): A multirelational perspective. International Journal of Inclusive Education. doi:10.1080/13603116.2019.1581280

Lundahl, L., Lindblad, M., Lovén, A., Mårald, G., \& Svedberg, G. (2017). No particular way to go. Journal of Education and Work, 30(1), 39-52.

Mårtensson, Å., Andersson, P., \& Nyström, S. (2019). A recruiter, a matchmaker, a firefighter: Swedish vocational teachers' relational work. Nordic Journal of Vocational Education and Training, 9(1), 89-110.

Martin, A.J., \& Dowson, M. (2009). Interpersonal relationships, motivation, engagement, and achievement: Yields for theory, current issues, and educational practice. Australian College of Ministries Review of Educational Research, 79(1), 327-365.

Murray, C., \& Pianta, R.C. (2007). The importance of teacher-student relationships for adolescents with high incidence disabilities. Theory Into Practice, 46(2), 105-112.

Nordenbo, S.E., Søgaard Larsen, M., Tiftikçi, N., Wendt, E., \& Østergaard, S. (2008). Teacher competences and pupil achievement in pre-school and school: A systematic review carried out for the Ministry of Education and Research, Oslo. Copenhagen: Danish Clearinghouse for Educational Research, School of Education, University of Aarhus.

Nylund, M., \& Gudmundson, B. (2017). Lärare eller hantverkare? Om betydelsen av yrkeslärares yrkesidentifikation för vad de värderar som viktig kunskap på Bygg- och anläggningsprogrammet [Teacher or craftsman? The importance of vocational teachers' professional identification for what they regard as important knowledge in the building and construction programme]. Nordic Journal of Vocational Education and Training, 7(1), 64-87.

OECD. (2019). Secondary graduation rate (Indicator). doi:10.1787/b858e05b-en

Rising Holmström, M., Häggström, M., \& Kristiansen, L. (2015). Skolsköterskans rolltransformering till den hälsofrämjande positionen [School nurses' role transformations to the health-promotion position]. Nordic Journal of Nursing Research, 25(4), 210-217.

Roorda, D.L., Koomen, H.M.Y., Spilt, J.L., \& Oort, F.J. (2011). The influence of affective teacher-student relationships on students' school engagement and 
achievement: A meta-analytic approach. Review of Educational Research, 81(4), 493-529.

Ryan, R.M., \& Deci, E.L. (2000). Self-determination theory and the facilitation of intrinsic motivation, social development, and well-being. American Psychologist, 55, 68-78.

Sæle, R.G., Sørlie, T., Nergård-Nilssen, T., Ottosen, K.O., Bjørnskov Goll, C., \& Friborg, O. (2016). Demographic and psychological predictors of grade point average (GPA) in North-Norway: A particular analysis of cognitive/ schoolrelated and literacy problems. Educational Psychology, 36(10), 1886-1907.

Scheff, T.J. (1990). Microsociology: Discourse, emotion and social structure. Chicago: University of Chicago Press.

Skolverket. (2011). Läroplan för gymnasieskolan 2011, examensmål och gymnasiegemensamma ämnen. Stockholm: Skolverket.

Skolverket. (2012). Arbetet med att främja närvaro och att uppmärksamma, utreda och åtgärda frånvaro $i$ skolan - För grundskolan, grundsärskolan, specialskolan, sameskolan, gymnasieskolan och gymnasiesärskolan. Stockholm: Skolverket.

Skolverket. (2019). Statistik om gymnasieskolan. Retrieved 2. February, 2019, from

https://www.skolverket.se/skolutveckling/statistik/sok-statistik-omforskola-skola-ochvuxenutbildning?sok=SokC\&verkform=Gymnasieskolan\&omrade=Betyg $\% 2$ 0och \%20studieresultat\&lasar $=2017 / 18 \&$ run $=1$

Specialpedagogiska skolmyndigheten. (2015). Beviljad projektansökan för bidrag till "Särskilda Insatser i Skolan (SIS)" [Accepted project application for funding for 'Special Interventions in Schools'].

Temagruppen Unga i arbetslivet. (2013). 10 orsaker till avhopp: 379 unga berättar om avhopp från gymnasiet. Stockholm: Temagruppen Unga i arbetslivet, 2013:2.

Thurfjell, K. (2017). En av tre klarar inte gymnasiet. Dagens Nyheter. Retrieved 5. July, 2017, from https://www.svd.se/en-av-tre-klarar-inte-gymnasiet

Törrönen, J. (2002). Semiotic theory on qualitative interviewing using stimulus texts. Qualitative Research, 2(3), 343-362. 